\title{
EFEKTIVITAS PIJAT PERINEUM TERHADAP KEJADIAN RUPTUR PERINEUM PADA PERSALINAN SPONTAN PRIMIGRAVIDA
}

\author{
Yuliani Tangko', Asrawaty ${ }^{2}$, Ida Ariyanti ${ }^{3}$, \\ Noviyati Rahardjo Putri ${ }^{4}$, Isnu Kurnia ${ }^{5}$ \\ ${ }^{1,5}$ Magister Terapan Kesehatan, Poltekkes Kemenkes Semarang, Semarang, Indonesia \\ 2Jurusan Kebidanan, Poltekkes Kemenkes Palu, Indonesia \\ ${ }^{3}$ Jurusan Kebidanan, Poltekkes Kemenkes Semarang, Semarang, Indonesia \\ ${ }^{4}$ Program Studi Kebidanan, Fakultas Kedokteran, Universitas Negeri Sebelas Maret, \\ Surakarta, Indonesia
}

\begin{abstract}
Perineal rupture cases in Indonesian occur in women at the age of 25-30 years are 24\%, while at the age of 32-39 are 62\%. Perineal rupture can cause female organ dysfunction, bleeding, and infection. One way to prevent perineal rupture is to do perineal massage to increase blood flow and elasticity of the perineal. This study aims to analyze the effect of perineal massage on the incidence of spontaneous perineal rupture in primigravida normal deliveries. This research method uses a literature review by conducting searches on the PubMed, Science Direct, and Google Scholar databases. The literature used is written in English and Indonesian. The articles in this study were published in 2014-2018. The keywords used are Perineal Massage, Rupture Perineum, and Primigravida Normal Labor. From the 12 articles which had been obtained, 8 articles discuss the benefits of perineal massage to prevent perineal rupture, 1 article discusses the comparison of perineal massage with kegel exercise, 1 article discusses risk factors that can affect the occurrence of perineal rupture, 1 article discusses knowledge and the period of service of the midwife related to perineal massage and 1 article discusses perineal massage which does not provide benefits to perineal rupture but perineal massage is safe during delivery. Perineal massage can increase the elasticity of the perineal muscles, relax the perineal tissue, prevent perineal tears, facilitate the delivery process so that labor complications do not occur, and reduce maternal morbidity.
\end{abstract}

Keywords : perineal massage; perineal rupture; primigravida 


\section{PENDAHULUAN}

Persalinan adalah proses pengeluaran hasil konsepsi (janin dan plasenta) yang telah cukup bulan atau hampir cukup bulan dan dapat hidup di luar kandugan melalui jalan lahir atau jalan lain dengan bantuan atau tanpa bantuan (kekuatan sendiri) (I.B.G Manuaba, 2013). Proses persalinan dapat dipengaruhi oleh beberapa faktor yaitu fisik/ tenaga ibu, jalan lahir, janin, psikologi ibu dan penolong persalinan. Faktor jalan lahir mempunyai peranan penting baik sebelum maupun sesudah proses persalinan (Departemen Kesehatan Asuhan Persalinan Normal, 2008).

Menurut World Health
Organization (WHO) tahun 2009 ada 2,7 juta kasus robekan perineum pada ibu bersalin dan diperkirakan meningkat sebesar 6,3 juta pada tahun 2050 seiring dengan semakin tingginya bidan yang tidak mengetahui asuhan kebidanan dengan baik. Di Asia ruptur perineum merupakan masalah yang cukup banyak dalam masyarakat yaitu sebesar $50 \%$ dari ruptur perineum di dunia. Di Indonesia, ibu yang mengalami ruptur perineum pada umur 25-30 tahun sebesar 24\% sedangkan pada umur 32-39 tahun sebesar 62\% (Triyanti et al., 2017).

Kejadian ruptur perineum dapat dicegah dengan berbagai cara antara lain latihan kegel pada saat hamil, mengatur posisi yang benar saat meneran, yoga prenatal, dan pijat perineum. Pijat perineum adalah tehnik memijat perineum di kala hamil atau beberapa minggu sebelum melahirkan. Pijat perineum dapat meningkatkan aliran darah ke perineum dan vagina sehingga perineum dan vagina menjadi elastis. Pijat perineum juga membantu melemaskan otot-otot dasar panggul sehingga jaringan tersebut akan membuka tanpa resistensi saat persalinan untuk memudahkan lahirnya bayi. Pijat perineum dapat mencegah ruptur perineum dan episiotomi. Pijat perineum juga dapat membantu melunakkan jaringan perineum (Safrudin et al., 2009)

Ruptur perineum dapat menyebabkan komplikasi pada ibu seperti perdarahan, fistula yang dapat menyebabkan iskemia, hematoma serta infeksi pada masa nifas sebagai akibat dari perlukaan pada saat persalinan yang memudahkan kuman masuk ke dalam tubuh. Selain itu ruptur perineum juga dapat menyebabkan inkontinensia ani sehingga tubuh tidak mampu mengendalikan buang air besar. (William, 2003)

Persalinan dapat mengakibatkan perlukaan di sekitar vagina sehingga memicu terjadinya perdarahan. Untuk meminimalkan ruptur perineum perlu dilakukan pencegahan, salah satunya adalah pijat perineum. Pijat perineum bertujuan untuk meningkatkan relaksasi otot dasar panggul, meningkatkan aliran darah dan elastisitas perineum. Pijat 
perineum juga dapat membantu ibu menyiapkan mental menjelang persalinan (Badriah \& L, 2012).

Pijat perineum dapat dilakukan pada usia kehamilan $>34$ minggu atau sekitar 1-6 minggu sebelum bersalin. (Indrayani \& Tuasikal, 2020). Teknik pijat perineum sangat aman dan tidak berbahaya sehingga dapat dilakukan setiap hari selama 5-10 menit namun tidak dianjurkan untuk melakukan pijat perineum pada ibu yang memiliki infeksi saluran kemih maupun infeksi menular seksual seperti infeksi herpes dan jamur. Hal ini didukung oleh penelitian Savitri et al (2014) yang menyatakan bahwa kejadian laserasi perineum lebih tinggi pada kelompok kontrol dibandingkan dengan kelompok intervensi. (Savitri et al., 2015)

Berdasarkan latar belakang tersebut maka peneliti tertarik untuk melakukan literature review tentang efektifitas pijat perineum terhadap kejadian ruptur perineum pada persalinan primigravida sehingga diharapkan pijat perineum ini dapat dilakukan pada semua ibu hamil yang tidak mempunyai kontra indikasi dengan tujuan dapat membantu mengurangi komplikasi persalinan.

\section{METODOLOGI PENELITIAN}

\author{
Penelusuran literatur dilakukan \\ melalui database PubMed, Science \\ Direct, dan Google Scholar. Artikel yang \\ dipilih menggunakan bahasa Inggris dan
}

bahasa Indonesia, full text, dan dipublikasikan tahun 2014 - 2018. Artikel dalam bentuk skripsi dan tesis dikeluarkan. Tidak ada ketentuan jenis penelitian pada pemilihan artikel ini. Kata kunci yang digunakan adalah massase perineum, pijat perineum, ruptur perineum, primigravida, literatur review. Total artikel yang didapatkan sebanyak 275 artikel dan yang sesuai dengan kriteria sebanyak 8 artikel.

\section{HASIL PENELITIAN DAN BAHASAN}

Artikel dalam penelitian ini sebanyak 8 artikel penelitian terkait dengan manfaat pijat perineum terhadap ruptur perineum. Selain itu hasil penelitian juga dibahas terkait dengan faktor resiko laserasi perineum, perbandingan pijat perineum dengan teknik lain serta penerimaan ibu hamil terhadap teknik ini. Hasil penelitian disajikan pada tabel 1 tabel ekstraksi artikel penelitian 
Tabel.1 Tabel Ekstraksi Artikel Penelitian

\begin{tabular}{|c|c|c|c|c|}
\hline No. & Judul & Metode Penelitian & Tujuan Penelitian & Hasil \\
\hline 1. & $\begin{array}{l}\text { Pengaruh } \text { Pijat } \text { Perineum } \\
\text { Selama Masa Kehamilan } \\
\text { Terhadap Kejadian Ruptura } \\
\text { Perineum Spontan di Pmb } \\
\text { Shinta Nur Rochmayanti, } \\
\text { S.ST., M.Kes (Rochmayanti et } \\
\text { al., 2018) }\end{array}$ & $\begin{array}{l}\text { Desain penelitian quasi } \\
\text { dengan rancangan post } \\
\text { test only control group } \\
\text { design }\end{array}$ & $\begin{array}{l}\text { Untuk mengetahui pengaruh pijat } \\
\text { perineum selama masa } \\
\text { kehamilan terhadap kejadian } \\
\text { rupture perineum spontan }\end{array}$ & $\begin{array}{l}\text { Ada pengaruh pijat perineum selama kehamilan terhadap } \\
\text { rupture uteri. Stimulasi yang diberikan berupa pijatan dapat } \\
\text { membuat jaringan ikat dan kolagen lebih pada perineum } \\
\text { lebih elastis. }\end{array}$ \\
\hline 2. & $\begin{array}{l}\text { Hubungan Pijat Perineum } \\
\text { dengan Robekan Jalan Lahir } \\
\text { pada lbu Bersalin Primipara di } \\
\text { BPM Kecamatan Metro } \\
\text { Selatan Kota Metro (Anggraini } \\
\text { \& Martini, 2015) }\end{array}$ & $\begin{array}{l}\text { Rancangan penelitian } \\
\text { menggunakan desain } \\
\text { analitik case control }\end{array}$ & $\begin{array}{l}\text { Untuk mengetahui hubungan } \\
\text { antara pijat perineum dengan } \\
\text { robekan jalan lahir pada ibu } \\
\text { bersalin primipara di BPM } \\
\text { Kecamatan Metro Selatan Kota } \\
\text { Metro tahun } 2015\end{array}$ & $\begin{array}{l}\text { Ibu yang tidak melakukan pijat perineum mempunyai } \\
\text { potensi sebesar } 10 \text { kali lipat untuk mendapatkan robekan } \\
\text { perineum dibandingkan yang melakukan pijatan perineum. }\end{array}$ \\
\hline 3. & $\begin{array}{l}\text { Effect of perineal massage on } \\
\text { the incidence of episiotomy } \\
\text { and perineal laceration (Zare et } \\
\text { al., 2014) }\end{array}$ & $\begin{array}{lr}\text { Rancangan } & \text { penelitian } \\
\text { dengan } & \text { randomized } \\
\text { controlled clinical trial }\end{array}$ & $\begin{array}{l}\text { Untuk mengetahui pengaruh pijat } \\
\text { perineum pada kejadian } \\
\text { episiotomy dan laserasi perineum } \\
\text { pada kala dua persalinan }\end{array}$ & $\begin{array}{l}\text { Tidak ada pengaruh pijat perineum pada kejadian } \\
\text { episiotomy dan laserasi perineum pada kala dua } \\
\text { persalinan. } \\
\text { Pada kelompok intervensi persentase perineum utuh, } \\
\text { episiotomy dan laserasi adalah } 22,2 \%, 44,4 \%, 33,3 \% \text {. Pada } \\
\text { kelompok kontrol, persentase perineum utuh, episiotomy } \\
\text { dan laserasi adalah } 20,2 \%, 49,3 \%, 28,3 \% \text {. }\end{array}$ \\
\hline 4. & $\begin{array}{l}\text { Pengaruh Pemijatan Perineum } \\
\text { pada Primigravida terhadap } \\
\text { Kejadian Ruptur Perineum saat }\end{array}$ & $\begin{array}{l}\text { Rancangan penelitian } \\
\text { dengan quasi eksperimen } \\
\text { metode posttest only }\end{array}$ & $\begin{array}{l}\text { Mengetahui pijat perineum } \\
\text { terhadap rupture perineum pada } \\
\text { persalinan di BPM Kota Bengkulu }\end{array}$ & $\begin{array}{l}\text { Pijat perineum dapat mengurangi rupture perineum } \\
(p<0,05) \text {. Pada kelompok intervensi kejadian rupture } \\
\text { perineum sebesar } 21,4 \text { dibandingkan pada kelompok }\end{array}$ \\
\hline
\end{tabular}

Midwifery Care Journal, Vol. 2 No.4, Oktober 2021, e-ISSN 2715-5978 (online) I 122 


\begin{tabular}{|c|c|c|c|}
\hline $\begin{array}{l}\text { Persalinan di Bidan Praktek } \\
\text { Mandiri di Kota Bengkulu } \\
\text { Tahun } 2014 \text { (Savitri et al., } \\
\text { 2015) }\end{array}$ & control group design & tahun 2014 & kontrol sebesar $71,4 \%$. \\
\hline $\begin{array}{l}\text { Effectiveness of antenatal } \\
\text { perineal massage in reducing } \\
\text { perineal trauma and post- } \\
\text { partum morbidities: A } \\
\text { randomized controlled trial } \\
\text { (Ugwu et al., 2018) }\end{array}$ & $\begin{array}{l}\text { Metode penelitian yang } \\
\text { digunakan adalah } \\
\text { randomized controlled } \\
\text { trial }\end{array}$ & $\begin{array}{l}\text { Mengetahui efektivitas antenatal } \\
\text { perineal massage (APM) dalam } \\
\text { upaya mengurangi laserasi } \\
\text { perineum dan kesakitan ibu masa } \\
\text { postpartum }\end{array}$ & $\begin{array}{l}\text { APM mengurangi kejadian episiotomi dan meningkatkan } \\
\text { kejadian perineum utuh (perineum inteka) setelah } \\
\text { persalinan pervaginam. APM mengurangi risiko } \\
\text { inkontinensia flatus setelah melahirkan tanpa peningkatan } \\
\text { komplikasi ibu atau bayi. }\end{array}$ \\
\hline $\begin{array}{l}\text { Perbedaan } \text { Hasil Masase } \\
\text { Perineum dan Kegel Exercise } \\
\text { terhadap } \\
\text { Robekan Perineum pada } \\
\text { Persalinan (Rahayu et al., } \\
2015 \text { ) }\end{array}$ & $\begin{array}{l}\text { Desain penelitian adalah } \\
\text { pra eksperimen dengan } \\
\text { desain posttest only }\end{array}$ & $\begin{array}{l}\text { Tujuan penelitian ini adalah untuk } \\
\text { membandingkan pengaruh pijat } \\
\text { perineum dan senam kegel pada } \\
\text { ibu hamil usia } 35 \text { minggu dengan } \\
\text { kejadian robekan perineum }\end{array}$ & $\begin{array}{l}\text { Pijat perineum lebeih efektif untuk mengurangi kejadian } \\
\text { rupture perineum derajat II dan III. } \\
\text { Pada kelompok intervensi sebesar } 77,8 \% \text { kelompok pijat } \\
\text { perineum mengalami rupture derajat satu dan sisanya } \\
\text { mengalami laserasi yang lebih luas yaitu derajat dua dan } \\
\text { tiga. } \\
\text { Pada kelompok senam kegel sebesar } 50 \% \text { responden } \\
\text { mengalami rupture derajat satu dan sisanya mengalami } \\
\text { rupture dua dan tiga. }\end{array}$ \\
\hline $\begin{array}{l}\text { The Effect of Perineal } \\
\text { Massage on Perineal Tear } \\
\text { Case on Primigravida Pregnant } \\
\text { Mothers In Their Third } \\
\text { Trimester In Public Health } \\
\text { Center Care of Morokay } 2018\end{array}$ & $\begin{array}{l}\text { Desain penelitian adalah } \\
\text { quasy } \quad \text { experimental } \\
\text { desain }\end{array}$ & $\begin{array}{l}\text { Tujuan penelitian adalah untuk } \\
\text { mengetahui efek pijat perineum } \\
\text { terhadap robekan perineum pada } \\
\text { ibu hamil trimester III }\end{array}$ & $\begin{array}{l}\text { Terdapat perbedaan antara kelompok intervensi pijat } \\
\text { perineum dan kelompok kontrol dengan p value (0.005). } \\
\text { pijat perineum yang dilakukan pada ibu hamil trimester III } \\
\text { dapay mengurangi resiko laserasi pada perineum } \\
\text { persalinan kala II. }\end{array}$ \\
\hline
\end{tabular}


(Indrayani \& Tuasikal, 2020)

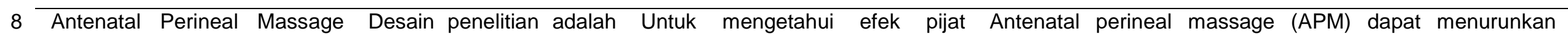
For Reducing Perineal Trauma randomised and quasi - perineum pada kejadian laserasi

(Beckmann \& Stock, 2013)

randomised controlled

perineum selama persalinan

laserasi primer perineum terutama yang disebabkan karena

episiotomi dan laserasi bukan karena episiotomi. Selain itu teknik ini diterima dengan baik oleh ibu. 
Manfaat Pijat Perineum Terhadap

\section{Ruptur Perineum}

Pijat perineum merupakan pijatan yang dilakukan di bagian perineum yaitu organ yang berada diantara vagina dan anus. Pijat perineum dapat dilakukan setiap hari selama 5-10 menit pada kehamilan 5-6 minggu terakhir. Pijat perineum yang dilakukan selama kehamilan akan membantu jaringan di sekitar perineum menjadi elastis (Safrudin et al., 2009). Manfaat pijat perineum dapat membantu meregangkan jaringan bagian dalam bawah vagina dan merelaksasikan otot dasar panggul (Sarwono, 2008). Chapman juga mengemukakan bahwa pijat perineum bermanfaat sebagai mekanisme koping ibu yaitu untuk menghilangkan rasa takut dan cemas saat persalinan. Pijat perineum yang dilakukan pada saat antenatal dimulai pada kehamilan 34 minggu akan mengurangi kemungkinan trauma perineum, membantu mengurangi tindakan episiotomi dan resiko laserasi perineum (Indrayani \& Tuasikal, 2020; Yuliaswati, 2014). Kencam et al. juga mendapatkan bahwa pemijatan perineum dapat menurunkan jumlah ruptur perineum. Wewet (2014) membuktikan bahwa pada kelompok intervensi yang dilakukan pijat perineum terjadi ruptur perineum sebanyak $21,4 \%$ lebih sedikit dibandingkan pada kelompok kontrol yang tidak dilakukan pijat perineum yaitu sebanyak $71,4 \%$
Penelitian yang dilakukan oleh Ugwu (2018) menemukan bahwa ibu yang dilakukan pijat perineum memiliki perineum yang utuh setelah melahirkan sebanyak 59\% lebih tinggi dibandingkan dengan ibu yang tidak dilakukan pijat perineum sebanyak $29,1 \%$ sehingga insiden episiotomi secara signifikan lebih rendah pada pijat perineum. Berkurangnya tindakan episiotomi dapat mengurangi rasa sakit dan kejadian inkontinesia flatus pada ibu nifas sehingga kebutuhan akan analgesia postpartum akan berkurang (Ugwu et al., 2018).

Pijat perineum dapat merangsang jaringan ikat dan kolagen pada perineum sehingga menyebabkan perineum menjadi elastis, fleksibel dan lentur ketika perineum meregang pada saat persalinan. Untuk itu perlu dilakukan pemijatan perineum guna membantu melunakkan jaringan perineum. Teori ini didukung oleh penelitian yang dilakukan Kusumawati et al (2018) yang menyimpulkan bahwa lama kala II lebih pendek pada ibu yang melakukan pijat perineum dibandingkan dengan ibu yang tidak melakukan pijat perineum (Indrayani \& Tuasikal, 2020). Teknik pijat perineum dilakukan waktu hamil atau beberapa minggu sebelum melahirkan bertujuan untuk meningkatkan elastisitas perineum dan aliran darah ke daerah perineum sehingga kejadian ruptur perineum dan episiotomi dapat dicegah (Rochmayanti et al., 2018). 
Penelitian Anggraini et al (2015) didapatkan hubungan pijat perineum dengan robekan jalan lahir pada ibu bersalin. Ibu yang tidak melakukan pijat perineum berpeluang mengalami 10,280 kali lebih besar mengalami ruptur perineum dibandingkan dengan ibu yang melakukan pemijatan perineum (Anggraini \& Martini, 2015)

\section{Faktor Resiko Terjadinya Ruptur Perineum}

Faktor-faktor penyebab ruptur perineum pada persalinan terdiri dari faktor ibu, faktor janin dan penolong persalinan. Pada ibu yang baru pertama kali melahirkan hampir semua terjadi ruptur perineum dan tidak jarang terjadi pada persalinan berikutnya. Ini disebabkan karena pada ibu yang pertama kali melahirkan perineum masih kaku sehingga tidak bisa menahan tegangan yang kuat pada saat persalinan dan akan mengakibatkan robekan perineum (William, 2003). Hal ini didukung juga teori bahwa ibu yang baru pertama kali melahirkan memiliki resiko lebih besar untuk mengalami ruptur perineum disebabkan karena jalan lahir belum pernah dilalui kepala bayi sehingga perineum belum meregang (Wiknjosastro, 2009). Teori ini berbeda dengan hasil penelitian yang dilakukan oleh Dempi et al (2017) dan Febri yang menyimpulkan bahwa tidak ada hubungan antara paritas dengan kejadian ruptur perineum yaitu pada primipara terjadi ruptur perineum
$67,1 \%$ dan pada multipara sebanyak 78,6 $\%$. Hasil penelitian ini juga menyimpulkan bahwa teknik mengejan juga dapat mempengaruhi terjadinya ruptur perineum (Triyanti et al., 2017). Hal ini sesuai dengan teori yang dikemukakan olen Manuaba (2010) yang mengatakan bahwa tehnik meneran yang benar sesuai dengan dorongan alamiah selama kontraksi (Ida Bagus Gde Manuaba, 2010).

Beberapa hal yang bisa dilakukan untuk mengurangi resiko terjadinya ruptur perineum saat melahirkan yaitu senam kegel, komsumsi makanan dengan gizi seimbang, mengejan dengan baik dan benar, pijat perineum selama 5-10 menit setiap hari saat 4-6 minggu sebelum melahirkan (Tobah, 2018).

Faktor umur saat persalinan juga dapat mempengaruhi terjadinya ruptur perineum. Umur yang optimal untuk reproduksi yaitu 20 - 35 tahun. Pada umur kurang dari 20 tahun organ-organ reproduksi belum berfungsi dengan sempurna sehingga lebih muda tejadi ruptur perineum dan komplikasi yang lain, selain itu kekuatan otot-otot perineum dan otot-otot perut belum bekerja secara optimal sehingga sering terjadi persalinan lama dan macet. Sedangkan pada usia diatas 35 tahun fungsi reproduksi wanita sudah mengalami penurunan (Safrudin et al., 2009). Namun pada ibu yang memiliki usia reproduksi sehat dapat mengalami laserasi perineum apabila kurang olahraga 
karena mengakibatkan kelenturan jalan lahir berkurang. Begitu juga dengan ibu yang terkena infeksi jalan lahir akan mengakibatkan jaringan ikat otot akan menjadi kaku sehingga mudah terjadi ruptur atau laserasi perineum (Aulia, 2011). Perineum yang kaku dapat membuat ruptur yang luas tak terhindarkan. Sekitar $70 \%$ ibu yang melahirkan pervagina mengalami trauma perineum (Sarwono, 2008)

\section{Perbandingan Pijat Perineum Dengan Kegel Exercise}

Penelitian yang dilakukan Rahayu et al (2015) menemukan bahwa pijat perineum lebih baik daripada senam kegel. Hasil penelitian menggambarkan sebesar $77,8 \%$ kelompok pijat perineum mengalami rupture derajat satu dan sisanya mengalami laserasi yang lebih luas yaitu derajat dua dan tiga. Pada kelompok senam kegel sebesar 50\% responden mengalami rupture derajat satu dan sisanya mengalami rupture dua dan tiga. Kedua intervensi dilakukan pada usia kehamilan 35 minggu. Peneliti menyimpulkan bahwa perbedaan ini mungkin disebabkan oleh karena dalam senam kegel yang dilakukan berulangulang dalam sehari kurang efektif. Indikator keberhasilan dalam melakukan senam kegel adalah saat buang air kecil tiba-tiba menghentikan pancaran air seni dengan melakukan kontraksi atau menguncupkan otot-otot ini kemudian mengendurkan lagi sehingga pancaran air seni kembali lancar (Rahayu et al., 2015)

\section{Pijat Perineum Tidak Memberikan} Keuntungan Tetapi Aman Dilakukan

Zero et al (2014) mengemukakan bahwa pijat perineum dengan menggunakan pelumas steril yang dilakukan bidan saat dilatasi penuh serviks selama 5-10 menit terhadap 45 responden, tidak signifikan dengan hasil insiden pada kelompok intervensi perineum utuh $22,2 \%$, episiotomi $44,4 \%$, dan laserasi $33,3 \%$ sedangkan pada kelompok kontrol perineum utuh $20,2 \%$, episiotomi 49,3\% dan laserasi $28,3 \%$. Hasil penelitian ini menunjukkan bahwa pijat perineum dengan menggunakan jari dan pelumas steril tidak memberikan keuntungan dalam mengurangi ruptur perineum namun aman dilakukan saat persalinan (Zare et al., 2014).

\section{KESIMPULAN}

Pemijatan perineum merupakan peregangan lembut pada kulit antara daerah perineum dan anus. Pemijatan perineum apabila dilakukan selama 5-10 menit setiap hari secara teratur mulai pada kehamilan 34 minggu atau dimulai saat trimester III akan mengurangi kejadian ruptur perineum sampai dengan 10 kali lipat dan tindakan episiotomi. Manfaat Pijat perineum yaitu membantu otot-otot perineum dan vagina jadi elastis, melancarkan aliran darah ke di daerah 
perineum dan vagina serta aliran hormon yang membantu melemaskan otot-otot dasar panggul sehingga proses persalinan lebih mudah. Untuk itu diharapkan bagi yang bekerja di tempat pelayanan kesehatan untuk memberdayakan tenaga kesehatan dalam mengatasi masalah ini secara bersama-sama.

\section{DAFTAR PUSTAKA}

1. Anggraini, Y., \& Martini, M. (2015). Hubungan Pijat Perineum dengan Robekan Jalan Lahir pada Ibu Bersalin Primipara di BPM Kecamatan Metro Selatan Kota Metro. Jurnal Kesehatan, 6(2), 155159.

2. Aulia, A. S. (2011). Faktor-Faktor Risiko Persalinan Seksio Sesearea di RSUD Dr. Adjidarmo Lebak pada Bulan Oktober-Desember 2010. Universitas Islam Negeri Syarif Hidayatullah Jakarta.

3. Badriah, \& L, D. (2012). Metodologi penelitian ilmu ilmu kesehatan. Bandung: Multazam.

4. Beckmann, M. M., \& Stock, O. M. (2013). Antenatal perineal massage for reducing perineal trauma. Cochrane Database of Systematic Reviews, 1, 1013-1021. https://doi.org/10.1002/14651858.CD0 05123.pub3

5. Departemen kesehatan Asuhan persalinan normal, (2008).
6. Indrayani, T., \& Tuasikal, N. (2020). The Effect of Perineal Massage on Perineal Tear Case on Primigravida Pregnant Mothers In Their Third Trimester In Public Health Center Care of Morokay 2018. STRADA Jurnal IImiah Kesehatan, 9(2), 588592.

https://doi.org/10.30994/sjik.v9i2.346

7. Manuaba, I.B.G. (2013). IImu Kebidanan , Penyakit kadungan \& keluarga Berencana. Jakarta: Rineka Cipta.

8. Manuaba, Ida Bagus Gde. (2010). IImu Kebidanan dan Penyakit Kandungan dan Keluarga Berencana untuk Pendidikan Bidan. Jakarta: Rineka Cipta.

9. Rahayu, S., Sumarni, S., \& Umaroh. (2015). The Difference Result of Perineal Massage and Kegel Exercise toward Preventing of Perineal Laceration during Labor Perbedaan Hasil Masase Perineum dan Kegel Exercise terhadap Pencegahan Robekan Perineum pada Persalinan. 4(2), 728-733.

10. Rochmayanti, N., Shinta, Ummah, \& Kholifatul. (2018). Pengaruh Pijat Perineum Selama Masa Kehamilan Terhadap Kejadian Ruptura Perineum Spontan di PMB Shinta Nur Rochmayanti, SSiT.,M.Kes. Jurnal Kebidanan Universitas Islam Lamongan, 10(1).

11. Safrudin, Ester, M., \& Wahyuningsih, 
E. (2009). Kebidanan Komunitas. ECG.

12. Sarwono, P. (2008). Ilmu Kandungan. Yayasan Bina Pustaka. Yayasan Bina Pustaka Sarwono Prawirohardjo.

13. Savitri, W., Ermawati, E., \& Yusefni, E. (2015). Pengaruh Pemijatan Perineum pada Primigravida terhadap Kejadian Ruptur Perineum saat Persalinan di Bidan Praktek Mandiri di Kota Bengkulu Tahun 2014. Jurnal Kesehatan Andalas, 4(1), 83-88. https://doi.org/10.25077/jka.v4i1.204

14. Tobah, Y. B. (2018). Can Vaginal Tears During Chilbirth be Prevented? Mayo Clinic.

15. Triyanti, D., Ningsih, S. S., Anesty, T. D., \& Rohmawati, S. (2017). Faktorfaktor yang berhubungan dengan kejadian ruptur perineum pada ibu bersalin di BPM Fauziah Hatta Palembang tahun 2017. 5(February), 152-159.

16. Ugwu, E. O., Iferikigwe, E. S., Obi, S. N., Eleje, G. U., \& Ozumba, B. C. (2018). Effectiveness of antenatal perineal massage in reducing perineal trauma and post-partum morbidities: A randomized controlled trial. 44(7), 1252-1258.

https://doi.org/10.1111/jog.13640

17. Wiknjosastro, G. H. (2009). IImu Kebidanan. Yayasan Bina Pustaka Sarwono Prawirohardjo.

18. William, H. O. (2003). Oxorn H (2003). Ilmu kebidanan: Patologi dan fisiologi persalinan. Yogyakarta: Yayasan Essentia Medica, pp: 425428.

19. Yuliaswati, E. (2014). faktor dominan yang menyebabkan bidan tidak melakukan pijat perineum yaitu faktor pengetahuan, sikap, pengalaman, motivasi dan budaya. 11(2), 7-14.

20. Zare, O., Pasha, H., \& Faramarzi, M. (2014). Effect of perineal massage on the incidence of episiotomy and perineal laceration. January. https://doi.org/10.4236/health.2014.61 003 